Paweł Hanczewski

Nicolaus Copernicus University, Toruń, Poland

ORCID: 0000-0003-4164-6310

e-mail: ph@umk.pl

\title{
The Union of 1707 and the Scottish Enlightenment
}

DOI: http://dx.doi.org/10.12775/RF.2018.024

In one of his letters to Gilbert Elliot, David Hume inserted a passage that is known to virtually every student of the Scottish Enlightenment: 'Is it not strange that, at a time when we have lost our Princes, our Parliaments, our independent Government..., is it not strange, I say, that in these Circumstances we shou'd really be the People most distinguish'd for Literature in Europe?' ${ }^{\prime 1}$ His words can be approached from different perspectives, including the sense of intellectual superiority shared by many Enlightenment thinkers, but they also reflect a notion that the Union of 1707 provided a political framework for serious changes in Scotland that led to the birth of what we know as the Scottish Enlightenment. Hume was not alone in his opinion. William Robertson wrote: 'adopted into a constitution whose genius and laws were more liberal than their own, they [the Scots] have extended their commerce, refined their manners, made improvements in the elegancies of life, and cultivated the arts and sciences'. ${ }^{2}$ This stance is echoed by those scholars who stress that, while the intellectual and cultural origins of the Scottish Enlightenment can be traced back as early as the $15^{\text {th }}$ century, the English-Scottish union of 1707 led to the gradual stabilization of political life as well as economic and social development, creating the conditions for rapid in-

1 Quoted in: Roy Porter, Enlightenment: Britain and the Creation of the Modern World (London: Penguin Books, 2001), 243.

2 William Robertson, "History of Scotland," in The Works of William Robertson, ed. Dugald Stewart (London: T. Cadell, 1827), 247. 
tellectual and cultural progress. ${ }^{3}$ A similar opinion, this time with reference to England, was advanced by Roy Porter in his highly acclaimed book in which he presented the Glorious Revolution as a necessary political step towards the birth of the English Enlightenment. ${ }^{4}$

Historians working on the Union of 1707 concentrate their attention on its political, economic and religious aspects, and the majority of them agree that in 1707 Scotland sold its political independence for free trade with England. Depending on one's views, this can be seen as an act of national treachery, especially given the large-scale political corruption sponsored by the English or as an evidence of far reaching political wisdom. ${ }^{5}$ The problem with both interpretations, as well as with the opinions of Hume and Robertson, is that they lack profound reflection on the opinions of Scottish politicians and political writers in the period before 1707, concerning the internal and external situation of their native country as well as its relations with England. The union was a political act of enormous importance, but it was not limited to the decisions taken by English and Scottish statesmen. Between 1698 and 1707 more than 60 pamphlets were written by Scottish authors on various aspects of Scotland's condition and its links with England. It is quite a different story whether they had any influence on politicians, but opinions expressed in those pamphlets deserve close attention on their own terms as they offer an opportunity to learn about the political, economic, social, religious and national ideas prevailing in Scotland in the early $18^{\text {th }}$ century.

Professor John Robertson has published several works on the political and social views of Andrew Fletcher of Saltoun, but because of his concentration on Fletcher and, paradoxically, the excellence of his research, Robertson has given the impression that the entire debate prior to the union of 1707 was very largely dominated by this single person. ${ }^{6}$

3 Nicholas Phillipson, "Towards a Definition of the Scottish Enlightenment," in City and Society in the $18^{\text {th }}$ Century, eds. Paul Fritz, David Williams (Toronto: Hakkert, 1973), 99-124; Alexander Broadie, The Scottish Enlightenment: The Historical Age of the Historical Nation (Edinburgh: Birlinn, 2001), 8-13; Arthur Herman, The Scottish Enlightenment: The Scots' Invention of the Modern World (London: Fourth Estate, 2001), 22-25.

4 Porter, Enlightenment, 14, 22-34.

5 John Young, "The Parliamentary Incorporating Union of 1707: Political Management, Anti-Unionism and Foreign Policy," in Eighteenth Century Scotland: New Perspectives, eds. Thomas Devine, John Young (East Linton: Tuckwell Press, 1999), 24-46; Christopher Whatley, Bought and Sold for English Gold? Explaining the Union of 1707 (Glasgow: Economic and Social History Society of Scotland, 1994); Paul Scott, The Union of 1707 why and how? (Edinburgh: The Saltire Society, 2006); Douglas Watt, The Price of Scotland: Darien, Union and the Wealth of Nations (Edinburgh: Luath, 2006).

6 John Robertson, The Scottish Enlightenment and the Militia Issue (Edinburgh: John Donald, 1985), 22-59; idem, "Andrew Fletcher's Vision of Union," in Scotland and England 1286-1815, ed. Roger Mason (Edinburgh: John Donald, 1987), 203-225; idem, 
This was not the case. My aim here, however, is not to present the detailed views expressed by particular authors in the above-mentioned pamphlets, but to address a question about the intellectual links between the debate that preceded the Union on the one hand and the Scottish Enlightenment on the other.

Searching for the intellectual links between people belonging to different generations, even if the time gap between them was relatively small, raises some serious difficulties that were presented in the most comprehensive way by Professor Quentin Skinner. ${ }^{7}$ Even if we assume that both the Scottish authors who were active in the early $18^{\text {th }}$ century and the Scottish Enlightenment thinkers wrote 'as Scots, that is as people who had lived in, worked with, and in substantial measure been formed by the same institutions ${ }^{8}$ it should be stressed that both groups worked under different conditions. To what degree was their thinking influenced by this factor? Was the choice of their themes dictated by current political events or did it result from their intellectual interests and/or intellectual fashions? Should we look for common general themes, compare detailed views, or concentrate on methods they used in their thinking?

There are also controversies surrounding those involved in the preunion debate and those belonging to the Scottish Enlightenment. The Union of 1707 caused sharp divisions among Scotsmen. George Lockhart of Carnwath, one of the most outspoken critics of the union described its opponents as 'patriots', while its supporters were labelled with the disdainful name of 'the other sort of men'. ${ }^{9}$ The Scottish Enlightenment writers were also far from being united. There existed some clear differences, for instance concerning the role of providence in human history, between such important figures as the already mentioned Hume and Robertson, and these differences underline the simple fact that there was no a particular intellectual programme within the Scottish Enlightenment.

There is a temptation to regard those Scotsmen who opposed the Union of 1707 as defenders of the old world doomed to destruction by the forces of progress, in political terms by the incorporating union with England and in intellectual terms by the Scottish Enlightenment. Such an attitude fits well within Hume's opinion about the Scots of the past, 'the rudest perhaps, of all European Nations; the most necessitous, the

\footnotetext{
"An elusive sovereignty. The course of the Union debate in Scotland 1698-1707," in A Union for Empire. Political Thought and the British Union, ed. John Robertson (Cambridge: Cambridge University Press, 1995), 198-227.

Quentin Skinner, "Meaning and Understanding in the History of Ideas," History and Theory 8, no. 1 (1969): 3-53.

8 Broadie, Scottish Enlightenment, 15.

9 Daniel Szechi, ed., 'Scotland's ruine'. Lockhart of Carnwath's memoirs of the union (Aberdeen: The Association for Scottish Literary Studies, 1995), 6.
} 
most turbulent, and the most unsettled' ${ }^{10}$ The story, however, was much more complicated.

The pre-union discussion between 'patriots' and 'the other sort of men' concentrated on the sovereignty of Scotland. This theme was very different from the main interests of the Scottish Enlightenment thinkers, who, from a general perspective, concentrated their attention on various aspects of 'civil society'. This difference, however, says more about current politics than the intellectual life of Scotland. While early $18^{\text {th }}$ century authors faced the question about political future of their country, those working in the middle or in the second half of the century remained free from that question. The situation changes when we look into details. The discussion over the sovereignty of Scotland was carried in political and legal terms, but it also involved such issues as the economic condition of the country, the role of institutionalized religion in society and different concepts of the Scottish nation. These themes corresponded well with the Scottish Enlightenment studies of 'civil society', and it is quite easy to find numerous similarities within particular subjects. The economic discussion before the union concentrated on the question of how to make Scotland 'a rich country', and this issue dominated economic debates of the Scottish Enlightenment as well. ${ }^{11}$ Despite Adam Smith's criticism of the 'mercantile system', some early $18^{\text {th }}$ century authors on both sides predated his views on such important issues as the sources of wealth, the role of money in the economy and the main aim of economic activity, namely to raise the standard of living of all the country's inhabitants, not just to satisfy the desires of the rich and the privileged. Both, 'patriots' and the 'other sort of men' were considering the international situation and the role of Scotland on the European stage through the balance of power theory, the approach that was later adopted by Scottish Enlightenment thinkers, including Hume. ${ }^{12}$

At the same time, however, it is equally easy to find numerous differences between the pre-union debate on the one hand and the Scottish Enlightenment on the other. Both the 'patriots' and 'the other sort of men' reserved a much bigger role for the state in economic life than did Hume or Adam Smith, and they also differed as to the meaning of the term 'free trade', one of the key elements of Hume's and Smith's

10 Quoted in: Porter, Enlightenment, 243.

11 Istvan Hont, "The 'rich country - poor country' debate in Scottish classical political economy," in Wealth and virtue. The Shaping of Political Economy in the Scottish Enlightenment, eds. Istvan Hont, Michael Ignatieff (Cambridge: Cambridge University Press, 1983), 271-316.

12 David Hume, "Of the Balance of Power," in David Hume Essays Moral, Political, and Literary, ed. Eugene Miller (Indianapolis: Liberty Fund, 1987), 332-341. 
economic theories. ${ }^{13}$ The 'patriots' accepted the definition of the 'Scottish nation' that had already existed in the Middle Ages, identifying a Scot with a warrior protecting the independence of his country, without paying any attention to a set of features described as 'politeness' that played such an important role during the Scottish Enlightenment.

There is nothing surprising about the fact that there existed numerous similarities and differences at the same time. They point to the already mentioned diverse conditions as well as the richness of the political, economic and social ideas formed during the pre-union debate and during the Scottish Enlightenment. Similarities and differences of the same kind could be found within the Enlightenment itself, because, as has been repeated more and more often, there was not just one Enlightenment, no matter whether in Scotland, England or any other country in Europe. The search for intellectual links should concentrate instead on the way of reasoning adopted by early $18^{\text {th }}$ century and Scottish Enlightenment thinkers.

Needless to say, the terms 'Scottish Enlightenment thinkers" and 'the Scottish Enlightenment' raise some serious controversies, ${ }^{14}$ but out of numerous definitions of the latter term, I have decided to chose the one put forward by Professor Alexander Broadie. In one of his books Professor Broadie argues that the main feature of the Scottish Enlightenment was 'that we do the thinking for ourselves'. This meant the rejection of the dead hand of political and especially religious authority that set the limits to our thinking, rejection of 'arguments from authority', i.e.

13 George Ridpath, A Discourse upon the Union of Scotland and England. Humbly submitted to the Parliament of Scotland, by a Lover of his Country (Edinburgh, 1702), 48-52, 68; James Hodges, Essay upon the Union (London, 1706), 10; John Clerk, A Letter to a Friend Giving an Account how the Treaty of Union Has been Received here. And Wherein are contained, Answers to the most material Objections against it, with some Remarks upon what has been written by Mr. H and Mr. R. (Edinburgh, 1706), 27; William Black, Essay upon Industry and Trade, Shewing The Necessity of the One, The Conveniency and Usefulness of the other, and the Advantages of Both (Edinburgh, 1706), 27; William Seton, The Interest of Scotland in three Essays (1700), 47.

14 Nicholas Phillipson, Rosalind Mitchison, eds., Scotland in the Age of Improvement: Essays in Scottish History in the Eighteenth Century (Edinburgh: Edinburgh University Press, 1970); Anand Chitnis, The Scottish Enlightenment: A Social History (London: Croom Helm, 1976); Jane Rendall, The Origins of the Scottish Enlightenment, 1707-1776 (London: Macmillan, 1978); Roy Campbell, Andrew Skinner, eds., The Origins and Nature of the Scottish Enlightenment (Edinburgh: Donald, 1982); David Daiches, The Scottish Enlightenment: An Introduction (Edinburgh: Saltire Society, 1986); Alexander Broadie, ed., The Scottish Enlightenment: An Anthology (Edinburgh: Canongate,1997); Christopher J. Berry, The Social Theory of the Scottish Enlightenment (Edinburgh: Edinburgh University Press, 1997); Paul Wood, ed., The Scottish Enlightenment: Essays in Reinterpretation (Rochester N.Y.: University of Rochester Press, 2000); Alexander Broadie, ed., The Cambridge Companion to the Scottish Enlightenment (Cambridge: Cambridge University Press, 2003). 
'arguments in which the justification offered for affirming a given proposition is that the proposition has the support of an authority in the relevant field', ${ }^{15}$ and, at the same time, the adoption of an autonomous and rational assessment of the various aspects of the past and the present.

Contrary to often repeated opinions, based mainly on emotional speeches delivered at the Scottish Parliament by Fletcher and on popular protests in the streets of Edinburgh, ${ }^{16}$ the pre-union debate was conducted in terms that fit well within this definition. One of the best known voices against the union of 1707 was raised by John Hamilton, second Lord Belhaven. In his 'Mother Caledonia' speech he appealed to the emotions rather than to the intellect of the Scottish MPs, but the language and arguments that he used, 'For the Love of God then, my Lord, for the Safety and Welfare of our ancient Kingdom... We want no Means, if we unite;... we want neither Men, nor sufficiency of all manner of things necessary, to make a Nation happy... For my Part, in the Sight of God, and in the Presence of this honourable House, I heartily forgive every Man, and beg, that they may do the same to me... ${ }^{17}$ were very different from the ones used by contemporary Scottish political writers. All major themes were discussed by them in critical and rational terms.

As to the major political issue, namely the sovereignty of Scotland, both the 'patriots' and 'the other sort of men' agreed that after the union of the Crowns in 1603 their country had been gradually losing its sovereignty. ${ }^{18}$ This, however, did not lead them to the opinion that the best

15 Broadie, Scottish Enlightenment, 17.

16 Daniel Defoe to Robert Harley, Edinburgh 24 October 1706, quoted in: Paul Scott, 1707. The Union of Scotland and England in contemporary documents with a commentary (Edinburgh: Chambers for the Saltire Society, 1979), 55.

17 “Lord Belhaven's Speech against the Union," http://www.british-history.ac.uk/ report.aspx?compid=37672.

18 Andrew Fletcher, "Two Discourses Concerning the Affairs of Scotland," in Andrew Fletcher Political Works, ed. John Robertson (Cambridge: Cambridge University Press, 1997), 45; idem, "Speeches by a member of the Parliament which began at Edinburgh the $6^{\text {th }}$ of May, 1703," in Andrew Fletcher Political Works, ed. John Robertson (Cambridge: Cambridge University Press, 1997), 132-134, 141; Ridpath, A Discourse upon the Union of Scotland and England, 38; idem, Considerations upon the union of the two Kingdoms: with an account of the Methods taken by Ancient and Modern Governments, to effect an Union, without endangering the Fundamental Constitutions of the United Countries (1706), 48; James Hodges, The Rights and Interests of the Two British Monarchies, Inquir'd into, and Clear'd; With a special respect to An United or Separate State. Treatise I. Shewing The different Nature of an Incorporating and Federal Union; The Reasons why all Designs of Union have hitherto prov'd Unsuccessful; and the Inconsistency of an Union by Incorporation with the Rights, Liberties, National Interests, and Publick Good of Both Kingdoms (London, 1703), 8, 45; Szechi, “'Scotland's ruine'," 244-245; George Mackenzie, Parainesis Pacifica; or a perswasive to the Union of Britain. By a Person of Quality (London, 1702), 20; William Seton, Some Thoughts, on Ways and Means For making This Nation a gainer in Foreign Commerce; And for Supplying Its present Scarcity of Money (Edinburgh, 1705), 13-14. 
and the only solution was the termination of the union with England. Voices of this kind were very scarce and, even in the case of most of the Jacobites, were nothing more than a bluff. ${ }^{19}$ Both sides assumed that there would not be return to the situation before 1603. After the experience of the union of the Crowns they accepted the view that Scotland could not be fully separated from England. The major question they asked was what kind of a union with England should be adopted in order to regain Scotland's sovereignty. What was more, the issue of sovereignty was not seen as end in itself. It was discussed for practical reasons and in practical terms. All Scottish authors underlined that a new union with England should guarantee Scotland's sovereignty for without sovereignty Scotland would not be able to solve its most pressing political, economic and social problems, and this in turn would hinder the development of the country. The bone of contention was how to regain sovereignty understood as being 'govern'd by no Laws, but those of their [Scottish] own making'. ${ }^{20}$ 'Patriots' believed that it was possible through such improvements to the existing union as granting additional powers to the Scottish parliament and limiting the role of the monarchy. ${ }^{21}$ 'The other sort of men' saw the possibility of retaining sovereignty in an incorporating union that would replace the Kingdom of Scotland and the Kingdom of England with a new state. In this new state, empowered with one common sovereignty, the interests of all the parts would be treated on an equal basis and this would put an end to actual dominance of England within the already existing union of the Crowns..$^{22}$ In other words, while the 'patriots' were thinking within the framework of a 'composite state', their opponents wanted to replace it with a unitary state. This controversy made the entire discussion a part of the much wider debate that took place in most of Europe over the second half of the $17^{\text {th }}$ century and the whole of the $18^{\text {th }}$ century. ${ }^{23}$

19 Fletcher, "Speeches," 142, 147, 161; Patrick Abercromby, The Advantages of the Act of Security, Compar'd with These of the Intended Union: Founded on the Revolution Principles Publish'd by Mr. Daniel De Foe. Or, The Present Happy Condition of Scotland, with respect to the Certainty of its Future Honourable andAdvantegous Establishment; Demonstrated (1706), 32.

20 Hodges, Rights... Treatise I., 40.

21 Fletcher, "Speeches," 143, 167; Ridpath, Discourse, 124-125; idem, An Historical Account of the Antient Rights and Power of the Parliament of Scotland: Humbly offer'd to the Consideration of the Estates, when they come to settle Limitations for the next Successor. To which is prefix'd, A short Introduction upon Government in General (1703), VII-IX.

22 Seton, Interest, 37, 42, 46-49, 55-56; idem, Scotland's Great Advantages by an Union with England. Showen in a Letter From the Country, To a Member of Parliament (1706), 11; Clerk, Letter to a Friend, 40-41, 43.

${ }^{23}$ Helmut Koenigsberger, "Dominium Regale or Dominium Politicum et Regale. Monarchies and Parliaments in Early Modern Europe," in Politicians and virtuosi. Essays in early modern history, ed. Helmut Koenigsberger (London: Hambledon, 1985), 
The debate over the sovereignty was closely linked with economic issues. Both sides saw the economic situation of Scotland in the same light, blaming England for the country's very serious economic difficulties. They differed, however, in their assessment of the relationship between the economy and politics. The background to the controversy was provided by international economic competition. The 'patriots' noticed this element, but they considered it inferior to politics. They thought that actions taken by England, aimed at hindering the economic development of Scotland and its economic exploitation through an incorporating union, resulted from political factors. Thus, they assumed that the key element in solving the economic problems of Scotland lay in the field of politics. In order to achieve economic growth and prosperity, Scotland had to free itself from actual dependence on England. The Scottish parliament should pass necessary laws, modeled to a high degree on English laws, that would protect Scottish producers and merchants against foreign, including English, competition. Protectionism was seen as the key to the economic revival of the country. ${ }^{24}$ On their side, the supporters of the incorporating union assumed that economic competition was a constant and unvaried factor in the relations between all states, including Scotland and England. They saw it as independent from politics, derived from the competitive character of international trade and the constant and limited size of the international market. As a result, it was impossible to eliminate economic competition by getting rid of English political influence. Instead, the Scots should join the much bigger English economy and be provided with protection enjoyed by their English counterparts. Unlike 'the patriots' they believed that because of the economic changes that took place in the course of the $17^{\text {th }}$ century only centralized states, that had moved away from the model of a 'composite state', could survive and develop. ${ }^{25}$

1-25; John Elliott, "A Europe of Composite Monarchies," Past and Present no. 137 (November 1992): 48-71; John Robertson, "Union, State and Empire: The Britain of 1707 in its European setting,", in An Imperial State at War. Britain from 1689 to 1815, ed. Lawrence Stone (London: Routledge, 1994), 224-257; idem, "Empire and Union: Two Concepts of the Early Modern European Political Order," in Robertson, Union for Empire, 3-36.

24 A Letter Concerning the Consequence of an Incorporating Union, In Relation to Trade (1706) 7; Hodges, Rights... Treatise I., 52-53; idem, The Rights and Interests Of the Two British Monarchies. With a Special Respect to An United or Separate State. Treatise III. Containing Farther Inquiries into the Best Means for procuring a Happy Union betwixt the Two Kingdoms; with a Special Regard to the Argument, That the Making Both Nations ONE PEOPLE, must also Make them of ONE INTEREST (London, 1706), 8, 32, 34, 37.

25 Thomas Smout, "Introduction," in Sir John Clerk's Observations on the present circumstances of Scotland, 1730, ed. Thomas Smout, Miscellany of the Scottish History Society $4^{\text {th }}$ ser., 10 (Edinburgh: T. and A. Constable, 1965), 179; Seton, Some, 46-47; 
The interdependence between the domestic and the external situation of Scotland was even more visible in the case of the discussions about the international position of Scotland. All the participants in the debate saw the international situation in terms of 'the balance of power'.$^{26}$ Those 'patriots' who supported a federal union with England and 'the other sort of men' assumed that the rivalry between European powers deprived Scotland of any choice in international politics. The more so since Scotland played the role of a 'front zone' between England and France. Due to the internal security needs of England and its anti-French policy on the one hand, and the plans of Louis XIV on the other, which aimed at shifting the balance of power to his side and building a 'universal monarchy', the role left for Scotland was the one of a pawn in a game played by two superpowers. The only solution, which was more a question of necessity deriving from the escalation of political, military and economic competition between major powers, rather than one of a free choice, was a new union with England. International relations were drifting towards a situation in which several leading powers could decide the fate of all Europe and the European world, pushing smaller countries into actual political non-existence. Unlike the supporters of the Glorious Revolution, the followers of the Stuart dynasty believed that Scotland had a choice that was not limited either to the union with England and 'freedom' in the form demarcated by the Glorious Revolution or 'absolutism' and the role of a becoming a French satellite. Scotland could maintain its independence and its national dynasty exactly because of the competition between England and France. Behind this belief there was the conviction that in the European politics there was room not only for the major powers, but also for smaller countries.

A part of the debate concerned a concept of 'the Scottish nation'. The 'patriots' accepted the definition that had already existed in the Middle Ages. A characteristic feature of 'the Scottish nation', defined in opposition to other nations, especially the English one, was attachment to freedom understood as the independence of the Kingdom of Scotland..$^{27}$ 'The other sort of men' presented an entirely new approach to the issue of

A Second Letter, on the British Union (Edinb. $8^{\text {th }}$. of April 1706), 8; Mackenzie, Parainesis, 12 .

26 George Ridpath, The Great Reasons and Interests consider'd ament the Spanish Monarchy (1701), 21; Hodges, Rights... Treatise III, 119; Francis Grant, The Patriot Resolved. In a Letter To an Addresser, from his Friend; of the same Sentiments with himself, concerning the Union (1707), 17, 19; William Seton, Scotland's Great Advantages by an Union with England. Showen in a Letter From the Country, To a Member of Parliament (1706), 4.

27 Szechi, "'Scotland's ruine'," 239; Patrick Abercromby, The martial achievements of the Scots nation. Being an account of the lives, characters, and memorable actions of such Scotsmen who have signaliz'd themselves by the sword at home and abroad. And a survey of the military transactions wherein Scotland or Scotsmen have been remarkably concern'd, 
'the Scottish nation'. They broke both with the Medieval tradition, and the much more recent Protestant and Presbyterian traditions that identified 'the Scottish nation' with a particular religious denomination. They assumed that the political and economic changes that had taken place after 1603 forced a re-definition of the entire idea of 'the Scottish nation'. As a result, they presented the concept of the nation that expressed its identity not by a military struggle for independence or by a professed religion, but by everyday hard work. ${ }^{28}$ This did not mean that they were willing to give up a Scottish national identity or accept an English national identity. The former was to be retained, on the basis of the union treaty, by separate political, legal, educational, and religious orders at the local level, as well as by the participation of Scottish representatives and peers in the activities of the new British Parliament. 'The Scot' became a citizen working for his homeland - a Scotland that functioned within the framework of Great Britain. Such an ideal of 'the Scot' approximated to the ideal of a citizen presented by Joseph Addison, a citizen possessing a set of features described as 'politeness'. Paraphrasing the title of one of the most significant works on English history during the $18^{\text {th }}$ century, 'the other sort of men' perceived the Scots as 'a polite, commercial and industrious people'.$^{29}$

Another characteristic feature of the pre-union debate was the marginal role played by religious issues. To be sure, some 'patriots' did try to exploit them, but their efforts, because of the attitude of the Presbyterian Church, failed. Aiming to maintain its dominant position and playing the role of a 'national church', the General Assembly of the Church of Scotland carefully avoided any political involvement in either party. ${ }^{30}$ 'The other sort of men', in turn, avoided religious issues, fearing that they would provide additional arguments for their opponents. This does not mean that the debate was of a secular or anti-religious character. Rather it means that religion was not only treated as one of the elements of a much wider problem, but it was seen as of much less importance than political, economic and national issues.

The critical and rational thinking of the early $18^{\text {th }}$ century Scottish authors can also be observed in their treatment of history. The study of the past was one of the key elements of the Scottish Enlightenment. Early $18^{\text {th }}$ century Scottish writers paid as much attention to history,

from the first establishment of the Scots monarchy to this present time, 2 vols., (Edinburgh 1711-1716); Hodges, Rights... Treatise III, 75.

28 Clerk, Letter to a Friend, 43; Seton, Scotland's Great, 3-4.

29 Paul Langford, A Polite and Commercial People: England 1727-1783 (Oxford: Oxford University Press, 1992).

30 Jeffrey Stephen, Scottish Presbyterians and the Act of Union of 1707 (Edinburgh: Edinburgh University Press, 2007), 55-57, 100-101, 235. 
though there did exist certain differences in their attitude to the past. They did not ask a question that occupied Hume, Robertson and Francis Hutcheson, namely, why study history, nor did they produce any historical work, relying instead on the achievements of earlier generations. What they shared with the Enlightenment thinkers were some elements of their concept of history. Early $18^{\text {th }}$ century authors believed that the main purpose of historical studies was to provide people with knowledge not only about what happened, but also why it happened. They described the present condition of Scotland, but they also asked about the causes of the present condition, searching for them in a more or less distant past. Their history was as much descriptive as analytical. They also believed that the object of historical studies were facts and human nature alike. Answers to the question about causes were found in such human features as ambition, hate, self-love, vanity, but also friendship, generosity and public spirit. Consequently, they believed that human nature was basically the same, no matter whether in ancient times, the middle ages or in present times. The most important element of the concept of history that they shared with the Enlightenment thinkers was that the study of history was future oriented. Early $18^{\text {th }}$ century Scottish authors did not exploit historical arguments in order to argue that Scotland should return to a Golden Age. They believed that there existed a link between the past and the future and that with sound knowledge of the past people could build a better world of tomorrow. The entire pre-union debate was not an attempt to turn back the clock. Its major aim, just as it was the major aim of the Scottish Enlightenment, was to improve the situation of the country and its people, though of course the proposed solutions differed to a high degree from each other. And, as with the Scottish Enlightenment, the pre-union debate challenged existing truths and wisdoms. Early $18^{\text {th }}$ century thinkers questioned the composite and unitary models of the state, some important elements of the mercantile system, the international order based on the dominance of great powers, and the medieval concept of the Scottish nation.

This is not to say that the pre-union debate was an integral part of the Scottish Enlightenment. Nor that the debate formed a kind of proto-Scottish Enlightenment. There is no point in multiplying Enlightenments. The debate lacked many themes that were of great importance in the later parts of the $18^{\text {th }}$ century, such as philosophy, literature and the arts, the physical and natural sciences. The critical reflection that was one of the key elements of the debate aimed at the improvement of the condition of Scotland, not at the gaining of freedom from political or religious authority by the people nor at individual progress. It is time, however, to stress that Hume, Robertson and other eminent figures of the Scottish Enlightenment that were so critical of Scotland of the early $18^{\text {th }}$ century, 
owed more in intellectual terms to their immediate predecessors than they were ever ready to admit.

\section{Bibliography}

A Letter Concerning the Consequence of an Incorporating Union, In Relation to Trade. 1706.

Abercromby, Patrick. The Advantages of the Act of Security, Compar'd with These of the Intended Union: Founded on the Revolution Principles Publish'd by Mr. Daniel De Foe. Or, The Present Happy Condition of Scotland, with respect to the Certainty of its Future Honourable andAdvantegous Establishment; Demonstrated. 1706.

Abercromby, Patrick. The martial achievements of the Scots nation. Being an account of the lives, characters, and memorable actions of such Scotsmen who have signaliz'd themselves by the sword at home and abroad. And a survey of the military transactions wherein Scotland or Scotsmen have been remarkably concern'd, from the first establishment of the Scots monarchy to this present time. 2 vols., Edinburgh 1711-1716.

Berry, Christopher. The Social Theory of the Scottish Enlightenment. Edinburgh: Edinburgh University Press, 1997.

Black, William. Essay upon Industry and Trade, Shewing The Necessity of the One, The Conveniency and Usefulness of the other, and the Advantages of Both. Edinburgh, 1706.

Broadie, Alexander, ed. The Cambridge Companion to the Scottish Enlightenment. Cambridge: Cambridge University Press, 2003.

Broadie, Alexander. The Scottish Enlightenment: An Anthology. Edinburgh: Canongate, 1997.

Broadie, Alexander. The Scottish Enlightenment: The Historical Age of the Historical Nation. Edinburgh: Birlinn, 2001.

Campbell, Roy and Andrew Skinner, eds. The Origins and Nature of the Scottish Enlightenment. Edinburgh: Donald, 1982.

Chitnis, Anand. The Scottish Enlightenment: A Social History. London: Croom Helm, 1976.

Clerk, John. A Letter to a Friend Giving an Account how the Treaty of Union Has been Received here. And Wherein are contained, Answers to the most material Objections against it, with some Remarks upon what has been written by Mr. H and Mr. R. Edinburgh, 1706.

Daiches, David. The Scottish Enlightenment: An Introduction. Edinburgh: Saltire Society, 1986.

Elliott, John. "A Europe of Composite Monarchies," Past and Present, no. 137 (November 1992): 48-71.

Grant, Francis. The Patriot Resolved. In a Letter To an Addresser, from his Friend; of the same Sentiments with himself, concerning the Union. 1707.

Herman, Arthur. The Scottish Enlightenment: The Scots' Invention of the Modern World. London: Fourth Estate, 2001. 
Hodges, James. Essay upon the Union. London 1706.

Hodges, James. The Rights and Interests of the Two British Monarchies, Inquir'd into, and Clear'd; With a special respect to An United or Separate State. Treatise I. Shewing The different Nature of an Incorporating and Federal Union; The Reasons why all Designs of Union have hitherto prov'd Unsuccessful; and the Inconsistency of an Union by Incorporation with the Rights, Liberties, National Interests, and Publick Good of Both Kingdoms. London 1703.

Hodges, James. The Rights and Interests Of the Two British Monarchies. With a Special Respect to An United or Separate State. Treatise III. Containing Farther Inquiries into the Best Means for procuring a Happy Union betwixt the Two Kingdoms; with a Special Regard to the Argument, That the Making Both Nations ONE PEOPLE, must also Make them of ONE INTEREST. London 1706.

Hodges, James. The Rights and Interests of the Two British Monarchies, Inquir'd into, and Clear'd; With a special respect to An United or Separate State. Treatise I. Shewing The different Nature of an Incorporating and Federal Union; The Reasons why all Designs of Union have hitherto prov'd Unsuccessful; and the Inconsistency of an Union by Incorporation with the Rights, Liberties, National Interests, and Publick Good of Both Kingdoms. London 1703.

Hont, Istvan. "The 'rich country - poor country' debate in Scottish classical political economy." In Wealth and virtue. The Shaping of Political Economy in the Scottish Enlightenment, edited by Istvan Hont, Michael Ignatieff, 271-316. Cambridge: Cambridge University Press, 1983.

Hume, David. "Of the Balance of Power." In David Hume Essays Moral, Political, and Literary, edited by Eugene Miller, 332-341. Indianapolis: Liberty Fund, 1987.

Koenigsberger, Helmut. “Dominium Regale or Dominium Politicum et Regale. Monarchies and Parliaments in Early Modern Europe." In Politicians and virtuosi. Essays in early modern history, edited by Helmut Koenigsberger, 1-25. London: Hambledon, 1985.

Langford, Paul. A Polite and Commercial People: England 1727-1783. Oxford: Oxford University Press, 1992.

Mackenzie, George. Parainesis Pacifica; or a perswasive to the Union of Britain. By a Person of Quality. London 1702.

Phillipson, Nicholas and Rosalind Mitchison, eds. Scotland in the Age of Improvement: Essays in Scottish History in the Eighteenth Century. Edinburgh: University Press, 1970.

Porter, Roy. Enlightenment: Britain and the Creation of the Modern World. London: Penguin Books, 2001.

Rendall, Jane. The Origins of the Scottish Enlightenment, 1707-1776. London: Macmillan, 1978.

Ridpath, George. A Discourse upon the Union of Scotland and England. Humbly submitted to the Parliament of Scotland, by a Lover of his Country. Edinburgh 1702.

Ridpath, George. An Historical Account of the Antient Rights and Power of the Parliament of Scotland: Humbly offer'd to the Consideration of the Estates, 
when they come to settle Limitations for the next Successor. To which is prefi$x^{\prime} d$, A short Introduction upon Government in General. 1703.

Ridpath, George. Considerations upon the union of the two Kingdoms: with an account of the Methods taken by Ancient and Modern Governments, to effect an Union, without endangering the Fundamental Constitutions of the United Countries. 1706.

Ridpath, George. The Great Reasons and Interests consider'd ament the Spanish Monarchy. 1701.

Robertson, John, ed. Andrew Fletcher Political Works. Cambridge: Cambridge University Press, 1997.

Robertson, John. "An elusive sovereignty. The course of the Union debate in Scotland 1698-1707,". In A Union for Empire. Political Thought and the British Union, edited by John Robertson, 198-227. Cambridge: Cambridge University Press, 1995.

Robertson, John. "Andrew Fletcher's Vision of Union". In Scotland and England 1286-1815, edited by Roger Mason, 203-225. Edinburgh: John Donald, 1987.

Robertson, John. "Empire and Union: Two Concepts of the Early Modern European Political Order". In A Union for Empire. Political Thought and the British Union, edited by John Robertson, 3-36. Cambridge: Cambridge University Press, 1995.

Robertson, John. “Union, State and Empire: The Britain of 1707 in its European setting". In An Imperial State at War. Britain from 1689 to 1815, edited by Lawrence Stone, 224-257. London: Routledge, 1994.

Robertson, John. The Scottish Enlightenment and the Militia Issue. Edinburgh: John Donald, 1985.

Robertson, William. History of Scotland. In The Works of William Robertson, edited by Dugald Stewart. London: T. Cadell, 1827.

Scott, Paul. 1707. The Union of Scotland and England in contemporary documents with a commentary. Edinburgh: Chambers for the Saltire Society, 1979.

Scott, Paul. The Union of 1707 why and how?. Edinburgh: The Saltire Society, 2006.

Seton, William. The Interest of Scotland in three Essays. 1700.

Seton, William. Scotland's Great Advantages by an Union with England. Showen in a Letter From the Country, To a Member of Parliament. 1706.

Seton, William. Some Thoughts, on Ways and Means For making This Nation a gainer in Foreign Commerce; And for Supplying Its present Scarcity of Money. Edinburgh 1705.

Skinner, Quentin. "Meaning and Understanding in the History of Ideas," History and Theory, vol. 8, no. 1 (1969): 3-53.

Smout, Thomas, ed., Sir John Clerk's Observations on the present circumstances of Scotland, 1730. Miscellany of the Scottish History Society, $4^{\text {th }}$ ser., 10, Edinburgh: T. and A. Constable, 1965.

Stephen, Jeffrey. Scottish Presbyterians and the Act of Union of 1707. Edinburgh: Edinburgh University Press, 2007. 
Szechi, Daniel, ed. Scotland's ruine'. Lockhart of Carnwath's memoirs of the union. Aberdeen: The Association for Scottish Literary Studies, 1995.

Watt, Douglas. The Price of Scotland: Darien, Union and the Wealth of Nations. Edinburgh: Luath, 2006.

Whatley, Christopher. Bought and Sold for English Gold? Explaining the Union of 1707. Glasgow: Economic and Social History Society of Scotland, 1994.

Wood, Paul, ed. The Scottish Enlightenment: Essays in Reinterpretation. Rochester N.Y.: University of Rochester Press, 2000.

Young, John. "The Parliamentary Incorporating Union of 1707: Political Management, Anti-Unionism and Foreign Policy." In Eighteenth Century Scotland: New Perspectives, edited by Thomas Devine and JohnYoung, 24-46. East Linton: Tuckwell Press, 1999.

\section{Summary}

The Union of 1707 was a political act of enormous importance, but it was not limited to the decisions taken by English and Scottish statesmen. Between 1698 and 1707 more than 60 pamphlets were written by Scottish authors on various aspects of Scotland's condition and its links with England. Their opinions deserve close attention on their own terms as they offer an opportunity to learn about the political, economic, social, religious and national ideas prevailing in Scotland in the early $18^{\text {th }}$ century. These opinions also allow to address a question about the intellectual links between the debate that preceded the Union on the one hand and the Scottish Enlightenment on the other. Despite the fact that the pre-union debate lacked many themes that were of great importance in the later parts of the $18^{\text {th }}$ century, such as philosophy, literature and the arts, the physical and natural sciences, there existed numerous intellectual links between early $18^{\text {th }}$ century Scottish political writers and such important figures of the Scottish Enlightenment as David Hume, William Robertson and Adam Smith.

Keywords: Union of 1707, Scottish Enlightenment, intellectual links

\section{Streszczenie}

\section{Unia z 1707 roku a szkockie oświecenie}

Unia angielsko-szkocka zawarta w 1707 roku była aktem politycznym o wielkim znaczeniu, ale nie ograniczała się do decyzji podjętych przez polityków. Między rokiem 1698 a 1707 autorzy szkoccy opublikowali ponad sześćdziesiąt broszur poświęconych sytuacji wewnętrznej ich kraju oraz jego relacjom z Anglią. Z wyjątkiem prac Andrew Fletchera of Saltoun, są one pomijane milczeniem przez historyków, którzy mimo upływu wielu lat od zawarcia unii nadal skupiają się na pytaniu, czy była ona aktem zdrady narodowej, czy rozsądną i dalekowzroczną decyzją. Opinie wyrażone we wspomnianych pracach zasługują na bliższe 
poznanie, ponieważ nie tylko pozwalają stwierdzić, jakie poglądy na kwestie polityczne, religijne, ekonomiczne i narodowe dominowały w Szkocji, ale też dowiedzieć się, czy istniał związek intelektualny między debata, która poprzedziła zawarcie unii, a szkockim oświeceniem. Mimo że w debacie brakowało kilku wątków, które przyciągały uwagę wybitnych postaci szkockiego oświecenia, między innymi Davida Hume'a, Adama Smitha czy Williama Robertsona, to należy stwierdzić, że pod wieloma względami debata z początku stulecia miała silny i trwały wpływ na rozwój intelektualny Szkocji przez cały wiek XVIII.

Słowa kluczowe: unia 1707 r., szkockie oświecenie, związki intelektualne 